\title{
1 IMPACT OF THE QUALITY OF ORGANIC AMENDMENTS ON SIZE AND COMPOSITION
}

\section{OF THE WEED SEED BANK}

3

4 B DE CAUWER ${ }^{*}$, T D'HOSE†, M COUGNON*, B LEROY*, R BULCKE* \& D REHEUL*

$5{ }^{\star}$ Department of Plant Production, Faculty of Bioscience Engineering, Ghent University,

6 Ghent, Belgium, and † Institute for Agricultural and Fisheries Research ILVO, Merelbeke,

7 Belgium

8

9 Running head: Effect of fertilizer quality on weed seed bank

10

11 Correspondence: B De Cauwer, Department of Plant Production, Faculty of Bioscience

12 Engineering, Ghent University, Coupure Links 653, B-9000 Ghent, Belgium. Tel: (+32) 9

13 2649064; Fax: (+32) 9 2649097; E-mail: Benny.decauwer@UGent.be

14

15 Word count $=6143$

16

17 REFERENCE:

18 De Cauwer B., D’Hose T., Cougnon M., Leroy B., Bulcke R. \& Reheul D. (2011). Impact of

19 the quality of organic amendments on size and composition of the weed seed bank. Weed

20 Research, 51(3), 250-260. 
In addition to improving the soil quality, organic amendments of soils may affect weed seed survival, emergence, growth and reproduction. This study evaluated the effects of applications of different qualities of organic amendments on size and composition of the weed seed bank in a field under sequential cropping over four years. Fertilisation systems tested included: farmyard manure, vegetable fruit and garden waste compost, two types of farm compost differing in carbon:nitrogen $(\mathrm{C}: \mathrm{N})$ ratio, cattle slurry and mineral fertiliser. All organically amended plots received equal amounts of C. Crop growth was equalised on all plots by applying supplemental mineral N. Seed bank sampling took place in May 2009 to a depth of $10 \mathrm{~cm}$. The weed seed bank was analysed with the seedling emergence method.

31 Despite equal crop growth in fertilised plots, total seed bank density was lowest in plots 32 amended with compost with low $\mathrm{C}: \mathrm{N}$ ratio and highest in slurry amended plots. Observed 33 differences in seed bank densities reflected differences in soil organic carbon content and 34 microbial biomass. At plot level, hard-coated seeds in the seed bank (e.g. Chenopodium spp.) were inversely related to soil microbial activity. Observed differential responses of species to applied fertilisers might be attributed to interspecific differences in resistance against microbial seed degradation. Compost based fertilisation systems could be

38 sustainable tools for incorporation into integrated weed control strategies aiming at depleting 39 the weed seed bank.

41 Keywords : Microbial biomass, fertilizer quality, compost, animal slurry, mineral $\mathrm{N}$ fertiliser, weed suppression, PLFA 


\section{Introduction}

Depletion of the soil seed bank is critically important in overcoming yearly weed infestations (Aldrich, 1984). Besides the prevention of seed return, a successful management system aimed at the depletion of the seed bank should also increase the seed mortality and manipulate weed germination and emergence (Riemens et al., 2007). Weed seed persistence in soil seed banks is thought to be determined by a combination of factors, including heritable traits, the maternal environment in which a seed develops, as well as soil biological, chemical, and physical properties (Gallagher \& Fuerst, 2005).

The addition of soil organic matter (SOM) changes nitrogen $(\mathrm{N})$ and carbon (C) turnover and soil microbiota, which may influence seed mortality, seed vigour and germination. Weed seed mortality rate, together with weed seed germination, determine soil seed bank depletion rate. The main mortality factors of seeds in the seed bank are natural physiological ageing, predation and attack by bacterial and fungal microorganisms. The relative importance of these mechanisms varies with species and environmental conditions. Biological activity (Kremer \& Li, 2003) and fungal colonisation of seeds (Pitty et al., 1987) in the soil are positively linked with SOM. Organic matter amendments may increase soil microbial biomass and activity (Fraser et al, 1988) and change the incidence and severity of soil-borne diseases of weeds (Conklin et al., 2002). Decomposability and nutrient availability of organic amendments will influence the composition of the soil biota, responsible for the breakdown or mineralisation of the applied organic matter. Microbial decomposition of organic matter is driven by the (chemical) composition of the organic matter (e.g. the C:N ratio)(Jensen et al., 2005). Raw manures, slurries and sewage sludge (low C:N ratio and hence high nutrient $(\mathrm{N})$ content) are mainly considered as nutrient suppliers, while stable organic amendments, like compost, add to SOM and improve soil structure. Weed seed germination and early growth is triggered by various factors, including soil temperature, soil moisture, light and soil nutrient concentrations (Karssen \& Hilhorst, 1992). In particular, mineral $\mathrm{NO}_{3}-\mathrm{N}$ and the timing of its application is known to stimulate germination of many 
71 weed seeds (Baskin \& Baskin, 1998; Sweeney et al., 2008). The chilling or light requirement 72 for seed germination in some species can be replaced by $\mathrm{N}$, particularly nitrate (Egley \& 73 Duke, 1985).

Kennedy and Kremer (1996) hypothesised that the soil environment could be manipulated to create "weed-suppressive soils" in which the microbial community

composition and activity deplete the weed seed bank, reduce possibilities of weed seedling establishment and reduce weed growth and competitive ability. Such soils might be created by the addition of manures and composts. The lack of knowledge about the impact of the quality of the organic amendments on microbes that degrade weed seeds or weed seedlings make the hypothesis prone to criticism.

The objective of this study was to evaluate the effects of continuous application of six different fertilisation systems on weed seed bank density and composition. Furthermore, the relationships between weed seed bank density, soil organic carbon content and microbial biomass were explored. Fertilisation systems tested included continuous application of one pure synthetic fertiliser and five organic fertilisers used in Belgian agriculture (i.e. three compost forms, animal slurry, farmyard manure). Organic fertilisation systems differed in the quality (e.g. C:N ratio) of the applied organic matter but not in quantity of applied organic carbon.

\section{Materials and methods}

\section{Field study}

A long-term field experiment was set up in 2005 at the experimental farm of Ghent University at Melle (Belgium, 5059' $\mathrm{N}, 039^{\prime} \mathrm{E}, 11 \mathrm{~m}$ above sea level). The field experiment was established on a sandy loam soil with $11.7 \%$ clay, $52.0 \%$ loam and $36.3 \%$ sand. Initial soil chemical properties of the field $(0-20 \mathrm{~cm})$ were: organic carbon $1.01 \%$, total $\mathrm{N} 0.086 \%$ and $\mathrm{pH}-\mathrm{KCl}=5.90$. Average annual rainfall (over 30 years) for this area was $718 \mathrm{~mm}$ and average minimum and maximum air temperature was $5.6^{\circ} \mathrm{C}$ and $13.5^{\circ} \mathrm{C}$, respectively. Prior 
to the experimental period, the study site was continuously cropped with minerally fertilised

100 maize for 22 years. During the experimental period, from 2005 until 2009, the field was

101 subsequently cropped with fodder beet (Beta vulgaris L.), winter wheat (Triticum aestivum

102 L.), red cabbage (Brassica oleracea L. var. rubra), perennial ryegrass (Lolium perenne L.)

103 and maize (Zea mays L.). After the harvest of the winter wheat, phacelia (Phacelia

104 tanacetifolia Benth.) was sown as a catch crop.

105 The field experiment was a randomised complete block design with four replicates

106 comparing six fertilisation systems: farmyard manure (FYM), vegetable fruit and garden

107 waste compost (VFG), two types of farm compost differing in $\mathrm{C}: \mathrm{N}$ ratio (CMC1 and $\mathrm{CMC2}$ ),

108 cattle slurry (CSL) and mineral fertiliser (MIN N). All amendments were supplied before

109 sowing or planting. All plots were $8 \times 6 \mathrm{~m}$ and arranged contiguously. Due to the use of a

110 microbial starter, which is added at the beginning of the composting process, farm compost

111 is often called CMC compost in which CMC stands for "controlled microbial composting".

112 CMC1 was composed of C-rich, woody material resulting in a final C:N ratio of ca. 20-40.

113 CMC2 was particularly made from green, N-rich materials and had a final C:N ratio of 10-20.

114 Based on the difference in starting materials and C:N ratio, CMC1 is generally believed to be 115 more fungi-dominated, while CMC2 is presumed to be more bacteria-dominated.

116 Fertiliser systems were scheduled in such a way that all organically amended plots

117 received equal amounts of organic $\mathrm{C}$, equal amount of plant available $\mathrm{N}$ during the growing

118 season and equal minimum levels of $\mathrm{K}$ and $\mathrm{P}$, allowing a comparable crop performance. By

119 using this design, differences in seed bank composition and density can reasonably be

120 attributed to the type or quality of organic fertiliser. Amounts of organic $\mathrm{C}$ applied varied from

1211101 to $4000 \mathrm{~kg} \mathrm{ha}^{-1}$ (Table 1). Initial doses were quite high, in order to speed up the

122 appearance of possible effects of the organic amendments. Perennial ryegrass received a

123 smaller quantity because it is known to build up much SOM by roots and stubbles. The catch

124 crop received less SOM than main crops. On the CSL plots, part of the organic C was

125 applied as crop residues (except before phacelia, red cabbage, perennial ryegrass and

126 maize) to avoid the input of an excessive amount of mineral N. At each amendment, extra 
127 mineral $\mathrm{N}$ (ammonium nitrate $27 \% \mathrm{~N}$ ) was applied, in order to equalise plant available $\mathrm{N}$

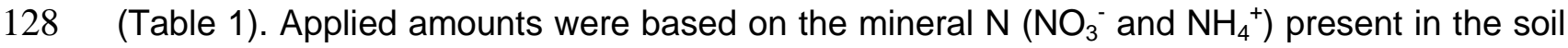
129 at the time of fertilisation and the (potential) mineralisation rates of the soil and of the organic 130 amendments, both determined by laboratory incubation (De Neve \& Hofman, 1996). Except

131 for the winter wheat, slurry-amended plots did not receive extra mineral N, since about $55 \%$

132 of the $\mathrm{N}$ contained in cattle slurry was in mineral form. At each fertiliser application, plots 133 were supplemented with muriate of potash $40 \%$ and triple superphosphate $45 \%$ to achieve 134 equal levels of plant available $\mathrm{K}_{2} \mathrm{O}\left(300 \mathrm{~kg} \mathrm{ha}^{-1}\right)$ and $\mathrm{P}_{2} \mathrm{O}_{5}\left(100 \mathrm{~kg} \mathrm{ha}^{-1}\right)$. Prior to sowing or 135 planting, organic amendments, as well as mineral $\mathrm{N}$ fertiliser, were applied manually on 136 cultivated and rotary harrowed plots. Organic amendments were incorporated to a depth of $13720 \mathrm{~cm}$ using a rotary tiller when preparing the seed-bed. Rotary tillage was preferred over 138 ploughing, in order to minimise horizontal transfer of fertilisers, seeds or microorganisms. All 139 mentioned tillage operations were performed on all plots including MIN N plots.

\section{Table 1 near here}

Cropland was placed under conventional pest management. Sowing and planting dates and pesticide applications from 2005 to 2009 were presented in Table 2.

Table 2 near here

Seed bank sampling

150 Seed banks were sampled on 13 May 2009, after sowing, in the central area $(6 \times 4 \mathrm{~m})$ of 151 each plot, to avoid seed transfer from adjacent plots by rotary tillage operation. Within this

152 central area 24 soil cores of $0-10 \mathrm{~cm}$ depth were taken on the intersections of a $1 \times 1 \mathrm{~m}$ grid 153 with a $4.0 \mathrm{~cm}$ diameter steel probe. The 24 soil cores from each area were combined to form 154 one bulked sample. Each bulked sample was further split into three subsamples. All samples 
155 were stored at $4^{\circ} \mathrm{C}$ for two weeks in darkness, before being washed within one week 156 consecutively through $4 \mathrm{~mm}$ and $0.2 \mathrm{~mm}$ sieves. All residues passing through the $4 \mathrm{~mm}$ 157 sieve but not through the $0.2 \mathrm{~mm}$ sieve were recovered and air dried for 3 days in a 158 glasshouse. The seedling emergence method was used to quantify seed density. Plastic 159 trays, $45 \times 45 \mathrm{~cm}$, were filled with a $2 \mathrm{~cm}$ layer of porous clay granules (Argex), covered by a

$1604 \mathrm{~cm}$ thick layer of sterilised peat. On top of this peat layer, the air-dried residue was spread

161 out evenly in a $1 \mathrm{~mm}$ layer and covered with a 1-2 mm layer of sterilised sieved (2 mm mesh)

162 peat. Concentrating the samples by wet sieving and using thin layers in the germination trays

163 ensured that all seeds were exposed to light and suitable temperatures The plastic trays 164 were kept for 12 months (1 June 2009- 15 June 2010) in a semi-open tunnel under a fine165 mesh gauze cover to avoid contamination by wind-borne seeds. Optimum moisture 166 conditions in the trays were maintained by regular sub-irrigation, except for a two-week 167 drought period imposed in August 2009 to break seed dormancy. At the end of the drought 168 period, trays were stirred and sub-irrigation was reactivated. The lowest night-temperature in 169 the tunnel was $-14^{\circ} \mathrm{C}$ and the maximum day-time tempe rature was $33^{\circ} \mathrm{C}$. Emerged seedlings 170 were periodically identified, counted and removed from the plastic trays. Seedling 171 identification was based on Hanf (1982). Nomenclature of species follows Van der Meijden 172 (2005). Owing to the combined effect of 1) dormancy breaking activities, such as cold 173 storage in refrigerator, dry periods, stirring, overwintering, leaching out of germination 174 inhibitors by washing with running water and scarification of the seeds on the sieves, 2) thin 175 seed layers in germination trays and 3) the long screening period, the measured active seed 176 bank closely reflected total viable seed bank. This was affirmed by squeezing the non 177 germinated seeds recovered from two randomly chosen test trays: only $1 \%$ of the larger 178 seeds remained firm when squeezed with forceps.

179 Weed seed bank density was calculated as the number of seedlings in the sampled 180 soil volume $(=3.01 \mathrm{~L})$ divided by the total surface area of 24 soil cores $\left(=0.0301 \mathrm{~m}^{2}\right.$, i.e. 181 surface area of the top of the core multiplied by 24) and finally expressed as the number of 182 seedlings per $\mathrm{m}^{2}$ to a depth of $10 \mathrm{~cm}$. Total weed seed bank density was defined as the sum 
183 of weed seed bank densities of all species. Relative density was calculated as the total

184 number of seedlings for a given species, divided by the total number of seedlings. Seed bank 185 numbers reflect germinable seeds, i.e. non-dormant seeds or seeds released from dormancy 186 during the seed bank screening period in the gauze tunnel.

188 Seed content in organic fertilisers

189 In order to take account of potential weed seed input from organic fertilisers, all organic

190 fertilisers were analysed for their content of germinable seeds. For each organic fertiliser 191 applied in 2009 and CSL and VFG applied in 2008, four random samples of $2 \mathrm{~kg}$ were taken 192 after mixing. Samples were washed through $0.2 \mathrm{~mm}$ sieves. The residue collected on the 193 sieve was further analysed for germinable seeds with the seedling emergence method 194 described above.

\section{Crop dry matter (DM) yield}

197 In order to reasonably attribute possible differences in seed bank composition and density to 198 fertiliser type or quality, crop biomass should be equal. This was checked by harvesting all crop plants in the central $2 \times 4 \mathrm{~m}$ of each plot. Fresh biomass samples were taken per plot, chopped and dried for $12 \mathrm{~h}$ at $75^{\circ} \mathrm{C}$ to calculate abo veground dry matter (DM) yield.

\section{Microbial biomass and composition and soil organic carbon content}

203 Analysis of phospholipid fatty acids (PLFAs) was performed, in order to explore relationships 204 between weed seed bank density and microbial biomass. PLFAs are essential membrane components of all living cells and make up a relatively constant proportion of the biomass of organisms. Owing to their rapid degradation after cell death, PLFAs are reliable measures of

207 the viable cell biomass. Preparation of PLFAs followed the modified Blight and Dyer 208 technique described by Balser (2001) and consisted of three steps, i.e. the extraction of the

209 lipids, the isolation of phospholipids and the methanolysis of these phospholipids resulting in 210 fatty acid methyl esters (FAMEs). These FAMEs were finally analysed by gas 
211 chromatograph-mass spectrometer analysis. The dataset of all fatty acids was further

212 simplified by using marker fatty acids of selected microbial groups following Kozdroj and van 213 Elsas (2001). For Gram-positive bacteria, the sum of iC15:0, aC15:0, iC16:0, iC17:0 and 214 aC17:0 was used. The fatty acid $c y C 17: 0$ was considered to be typical for Gram-negative 215 bacteria, while for the actinomycetes, the sum of the $10 M e$ fatty acids was regarded as a 216 reliable indicator. The $\mathrm{C} 18: 2 \omega 6,9 \mathrm{c}$ was used as a signature fatty acid for fungi. One bulked 217 sample per plot was analysed for PLFAs. Each bulked sample comprised 15 soil cores of 0$21810 \mathrm{~cm}$ depth taken in September 2007 in the central area $(6 \times 4 \mathrm{~m})$ of each plot. In autumn 2192008 , soil organic C content was measured by dry combustion at $1050^{\circ} \mathrm{C}$ using a TOC220 analyzer (Skalar). The $\mathrm{pH}$ was measured potentiometrically in a 1:2.5 soil: $\mathrm{KCl}$ extract.

\section{Statistical analysis}

223 Weed seed bank densities and weed emergence were fourth-root transformed to meet the 224 assumptions for homogeneity of variance and normality. SPSS15.0 for Windows was used to 225 carry out the statistical computations for analysis of variance of a randomised complete block 226 design, for linear correlation and regression analysis. Differences between treatment means were compared using Fisher's protected LSD test at the 5\% significance level.

Analysis of the weed community composition was performed on arcsin-transformed data of species relative density. The linear techniques Principal Components Analysis (PCA)

230 and Redundancy Analysis were used to analyse the weed seed bank composition (utilising 231 Canoco 4.5), because the gradients were short (<2 SED) (Ter Braak \& Smilauer, 1998). 232 Fertilisation systems (nominal variables) were included as dummy variables and inserted as 233 environmental variables in an indirect gradient analysis (RDA). The four replicates were 234 inserted as covariables. Significance of the eigenvalues $(\lambda)$ of the RDA ordination axes was 235 calculated using a permutation test. RDA followed by Monte-Carlo permutation test was used 236 to calculate the amount of variance in the species data explained by each treatment and its 237 statistical significance (Ter Braak \& Smilauer, 1998). 


\section{Results}

Seed content in organic fertiliser

242 Organic fertilisers, applied in 2009, contained on average 0.0, 2.5, 15.1, 1.2 and 3.3 viable 243 seeds per kg for VFG, CMC1, CMC2, CSL and FYM, respectively. So, taking into account 244 their applied amounts (Table 1), soil seed banks were enriched with 0.0, 6.3, 58.2, 11.5 and 24516.7 germinable seeds per $\mathrm{m}^{2}$ to a depth of $20 \mathrm{~cm}$ for VFG, CMC1, CMC2, CSL and FYM, respectively. VFG and animal slurry applied in 2008 contained on average 0.0 and 2.7 viable seeds per $\mathrm{kg}$, respectively. This corresponded to a seed input of 0.0 and 8.1 germinable seeds per $\mathrm{m}^{2}$ to a depth of $20 \mathrm{~cm}$ for VFG and CSL, respectively.

Weed seed bank density

251 In total, 32 species were recorded. Altogether they accounted for $98.4 \%$ of the total weed 252 seed bank density. Majors species contributing $\geq 0.5 \%$ to the total weed seed bank are 253 listed in Table 3.

Table 3 near here

Fertilisation system significantly affected total weed seed bank density (Table 3).

258 Total weed seed bank density was lowest in compost amended plots (CMC1, CMC2 and 259 VFG) and highest in slurry amended plots. Total weed seed bank density in minerally 260 fertilised plots was not significantly different from seed bank densities in organically amended 261 plots. Within organically amended plots, total weed seed bank density was significantly lower 262 in plots receiving VFG and CMC2 compost than in slurry amended plots.

263 The fertilisation system significantly affected weed seed bank density of Capsella 264 bursa-pastoris (L.) Medik., Cerastium glomeratum Thuill., Chenopodium album L., 265 Chenopodium polyspermum L., Lamium purpureum L. Plantago major subsp. major L., 266 Polygonum aviculare L. and Stellaria media L., but had no effect on Cardamine hirsuta L., 
Gnaphalium uliginosum L., Poa annua L., Polygonum maculosa Gray, Senecio vulgaris L.

and Solanum nigrum L. (Table 3). Compared with CSL plots, MIN N plots showed significantly lower seed density of S. media. Plots amended with CSL showed significantly higher seed densities of C. bursa-pastoris, C. album, and P. major subsp. major compared with CMC2 plots and higher densities of L. purpureum and S. media compared with VFG 272 plots. CMC2 plots showed significantly lower seed density of C. album than CMC1, CSL and 273 MIN N plots. VFG plots showed significantly lower seed density of L. purpureum than CMC1 274 plots. MIN N and CSL plots showed significantly lower seed densities of $P$. aviculare than 275 FYM and CMC1 plots. Within compost plots, seed density of $C$. album was significantly 276 higher for CMC1 plots.

Weed seed bank composition

279 The first two ordination axes of the RDA ( $\lambda=0.20$ and 0.11 respectively) were significant 280 ( $P \leq 0.002)$. Replicates were responsible for $27 \%$ of the variance in species data, whereas 281 treatments explained $18 \%$ of the variance. MIN N, CSL, CMC1, FYM and CMC2 explained $2826 \%, 4 \%, 3 \%, 4 \%$ and $1 \%$ of the total variance respectively. The first two axes of the PCA $(\lambda=$ 2830.26 and 0.12 respectively) were used to construct the PCA ordination diagram (Fig. 1). The 284 amount of variance in species data explained by the first two axes was $35 \%$ and $16 \%$ 285 respectively. Only the vectors of these species that had a fit of $4 \%$ or more to the diagram 286 and occurred in at least 5 plots were depicted in the ordination diagram. The positive side of 287 the first ordination axis is related to fertilisation system CMC1 with an inter-set correlation 288 coefficient of $0.35^{\star *}$. Species characterising the weed seed bank of CMC1 plots were $P$. 289 annua, Matricaria chamomilla L. and Sonchus oleraceus L.. Species such as S. nigrum, C. 290 hirsutum, G. quadriradiata, were ordinated towards the negative side of the first ordination 291 axis and were related to fertilisation system VFG, with an inter-set correlation coefficient of $2920.22^{\star}$. The positive side of the second ordination axis is related to fertilisation system MIN N 293 (inter-set correlation coefficient of $0.50^{\star *}$ ) and is characterised by C. album, C. polyspermum, 294 L. purpureum and P. maculosa. The negative side of the second ordination axis is related to 
295 fertilisation systems FYM (inter-set correlation coefficient of $-0.23^{\star *}$ ) and CSL (inter-set 296 correlation coefficient of $\left.-0.24^{\star \star}\right)$. Species associated with these fertilisation systems were 297 Epilobium ciliatum Rafin. and to a lesser extend G. uliginosum and P. major subsp. major.

Fig. 1 near here

Crop DM yield

302 The DM yields of cabbage heads and leaves, beet roots and leaves, ryegrass and maize 303 were similar for all fertilised plots, except for CSL plots showing lower DM yields of beet roots 304 and maize and for MIN N plots showing a lower yield of ryegrass (Table 4). Hence, the applied amounts of nutrients through the amendments and fertilisers were correctly 306 calculated.

Weed seed bank density in relation to soil organic $\mathrm{C}$ content, $\mathrm{pH}-\mathrm{KCl}$ and microbial biomass

311 Soil organic $\mathrm{C}$ content in minerally fertilised plots was significantly lower than in organically 312 amended plots (Table 5). Within organically amended plots, no significant differences in soil 313 organic carbon content were found. FYM, VFG and CSL plots showed significantly higher $314 \mathrm{pH}-\mathrm{KCl}$ than $\mathrm{CMC1}$ and MIN N plots. Fertiliser type affected microbial biomass (indirectly 315 measured by PLFA content) and community composition (Table 5). All organically fertilised 316 plots showed significantly higher PLFA contents of actinomycetes, Gram-positive and Gram317 negative bacteria than minerally amended plots. Within compost amended plots (VFG, 318 CMC1, CMC2), no significant differences in total microbial, fungal and bacterial PLFA 319 contents were found. Within organically fertilised plots, CMC1 plots had higher fungal PLFA 320 content and lower bacteria to fungi ratio than FYM and CSL plots. 
At plot level, soil organic carbon content is significantly $(P<0.05)$ positively related to

microbial biomass with a linear correlation coefficient of 0.48 . Total weed seed bank density was significantly negatively correlated with soil organic carbon content $(r=-0.44)$, total microbial biomass $(r=-0.34)$ and AFLP content of actinomycetes (Table 6, Figure 2).

Fig. 2 near here

Seed bank densities of the highly competitive weed $C$. polyspermum were significantly negatively correlated with bacterial (actinomycetes, Gram-positive and Gramnegative bacteria) and total microbial biomass, and $\mathrm{pH}-\mathrm{KCl}$, but not with soil organic $\mathrm{C}$ content (Table 6). Unlike $C$. polyspermum, seed bank density of $P$. aviculare was significantly positively correlated with bacterial and total microbial biomass. Seed density of $P$. major subsp. major revealed a weak negative correlation with biomass of Gram-positive bacteria.

Seed densities of $C$. bursa-pastoris, P. major subsp. major, P. maculosa and S. nigrum were not significantly correlated with total microbial, fungal or bacterial (except for the correlation between density of $P$. major subsp. major and AFLP content of Gram-positive bacteria) biomass despite their significant negative correlations with soil organic $\mathrm{C}$ content.

Table 6 near here

\section{Discussion}

No data on initial weed seed bank size are available, but the field was uniformly cropped with

347 maize before 2005, pesticidal control was uniform across the experimental site and weed

348 infestations were moderate. Seed rain from outside the plots is assumed to be very low and 349 identical across all plots because wind dispersible seeds were hardly produced in the maize 350 monoculture fields and intensively mown boundaries bordering the experimental field. Thus, 
351 it is reasonable to attribute differences in weed seed bank densities mainly to the treatments

352 imposed after 2005.

353 All organically amended soils revealed similar soil organic carbon contents, except for 354 the slurry amended soils showing lower values. The lower soil organic carbon content in slurry amended plots resulted in a lower amount of microbial biomass compared with plots receiving more stabile carbon forms. At plot level, soil carbon content was significantly correlated with microbial biomass.

Total weed seed bank density was lowest in compost amended plots (CMC1, CMC2 and VFG) and highest in slurry amended plots. These differences are unlikely to be explained by differences in crop competitiveness or amounts of viable seeds in the organic fertilisers. Indeed, aboveground DM biomass production was similar for all fertilised plots and content of germinable seeds in the applied organic fertilisers was very low compared to the seed bank content. Unlike manure, compost is not a significant source of viable seeds if properly composted (Eghball \& Lesoing, 2000). Manure or slurry may only be a relatively major source of weed seeds, if soil seed bank numbers are low (Pleasant \& Schlather, 1994). The higher seed bank numbers in slurry amended plots cannot be attributed to a lack of dormancy breaking: although these plots mostly did not receive extra ammonium nitrate (a well-known dormancy breaking agent), applied cattle slurry itself contained large amounts of mineral N. Therefore, it is more reasonable to attribute differences in seed bank density to differences in seed decay, seed production or seed predation. fungal and bacterial (except for Gram-negative bacteria) biomass and lower bacteria to fungi 373 ratios. Indeed, recalcitrant compounds are mainly decomposed by fungi, whereas readily decomposable compounds, such as organic acids and carbohydrates present in manure and 375 slurry, are preferentially utilised by soil bacteria (Marschner et al., 2003).

Definite evidence that soil microorganisms were responsible for the lower seed bank 377 density in compost plots cannot be provided, because differences in total microbial, fungal 378 and bacterial biomass were not significant in the short term. Nevertheless, lower seed bank 
densities were found in plots with high microbial activity, indicating that microbial seed deterioration might be higher in these plots, since nor specific low seed production, nor seed predation are assumed to be responsible for the low seed bank densities. Seed production was assumed to be low particularly for summer-germinating species because of the residual 383 effect of soil herbicides, high crop competitiveness and year-round soil coverage. Seed 384 predation is usually low in agricultural systems with intensive soil disturbance, seed burial by 385 tillage and lack of habitats for predators and for species with hard seed pericarps (Brust \& House, 1988).

Total weed seed density in minerally fertilised plots was comparable to the weed density in compost amended plots despite their lower soil organic carbon content, total microbial, fungal and bacterial biomass. The well known stimulating effect of ammonium nitrate on seed germination of many species (Karssen \& Hilhorst, 1992), combined with mortality due to spring herbicide application offers an acceptable explanation.

Plots amended with more stable carbon compounds, in particular VFG and CMC2 393 plots, showed lower seed densities of L. purpureum, C. album, C. bursa-pastoris, P. 394 maculosa, P. major subsp. major, P. annua and S. nigrum than plots amended with more readily decomposable compounds (CSL) or synthetic fertiliser (MIN N). These findings are in 396 line with studies reporting lower weed infestations by C. bursa-pastoris (Fennimore \& 397 Jackson, 2003) and C. album (Gallandt et al., 1999) in soils amended with organic fertilisers. 398 Within microbial groups, weed seed bank numbers on plot level were best correlated with 399 biomass of Gram-positive bacteria. Observed significant correlations between biomass of 400 Gram-positive bacteria and seed bank densities were negative for $C$. polyspermum and $P$. 401 major subsp. major, both species with long-term persistent hard-coated seeds, but 402 correlations were positive for S. vulgaris and S. media both species with transient or short403 term persistent seed banks. Interspecific differences in resistance against microbial 404 breakdown of seeds may be responsible for this differential response. Indeed, weed species 405 with short-lived seed banks appear to invest more in chemical defense than species with 406 highly persistent seed banks that rely mainly on physical seed protection (Davis et al., 2008). 
407 Hence, species with long-term persistent seed banks are more vulnerable to management 408 actions that reduce physical integrity of the weed seed coat, such as the use of organic 409 fertilisers that stimulate microbial activity. It is reasonable to explain the observed negative 410 correlation between seed bank densities of $C$. polyspermum and $P$. major subsp. major and 411 bacterial and total microbial biomass at plot level by the combined action of enhanced 412 microbial breakdown of their hard seed coat and weak chemical defense properties of their 413 seed coat. Apart from seed mortality by microbial invasion and decomposition of seeds, 414 some microorganisms are known to soften the impermeable seed coat by enzymes, thus 415 enabling seed germination (Gogue \& Emino, 1979). Unlike former hard-coated species, $P$. 416 aviculare was positively correlated with bacterial and total microbial biomass, despite its hard 417 seediness. It is well known that all plant parts of $P$. aviculare contain phytochemical 418 constituents, such as tannins, saponins and flavonoids with broad spectrum activity against 419 bacteria. So, diffusion of antimicrobial substance from $P$. aviculare seeds might limit or inhibit 420 potential seed decomposers particularly in bacteria-rich soils, adding a good chemical 421 defense strategy to a good physical defense strategy.

$422 \quad$ Fertiliser form and quality influenced weed seed bank composition, as shown by 423 multivariate seed bank analysis. The seed bank of minerally fertilised plots was characterised by species with hard seed coats, such as C. polyspermum, P. maculosa and C. album.

425 Probably, seeds of these species were less prone to microbial deterioration under prevailing 426 conditions of low microbial activity. Plots amended with VFG compost were associated with 427 late germinating weeds preferring nutrient-rich organic soils, such as G. quadriradiata and $C$. 428 hirsuta (winter annual).

\section{Conclusions}

431 The results presented in this study showed evidence for a significant short term effect of the 432 type and quality of organic amendments on the weed seed bank: seed bank numbers were 433 higher in plots amended with cattle slurry than in plots amended with compost with low C:N 434 ratio. Differences in seed bank numbers between compost and manure were moderate but 
435 might become more pronounced in the long term. Hence, fertiliser management can be a 436 promising and sustainable tool in integrated weed control strategies aiming at depleting the 437 soil seed bank. The correlation study provided indirect evidence that increased organic 438 matter content or microbial biomass (or both) have a potential to affect soil seed banks, 439 particularly those with high abundance of long-term persistent species with hard-coated 440 seeds. However, more fundamental research is necessary to provide conclusive evidence.

\section{References}

ALDRICH RJ (1984) Weed-Crop Ecology: Principles in Weed Management. Breton, North Scituate, Massachusetts, USA.

BALSER TC (2001) The impact of long-term nitrogen addition on microbial community composition in three Hawaiian forest soils. The Scientific World 1 (S2), 500-504.

BASKIN CC \& BASKIN JM (1998) Seeds: Ecology, Biogeography, and Evolution of Dormancy and Germination. Academic Press, New York, USA.

BRUST GE \& HOUSE GJ (1988) Weed seed destruction by arthropods and rodents in low-input soybean agroecosystems. American Journal of Alternative Agriculture 3, 19-25.

Conklin AE, Erich MS, Liebman M, Lambert D, Gallandt ER \& Halteman WA (2002) Effects of red clover green manure and compost soil amendments on wild mustard growth and incidence of disease. Plant and Soil 238, 245-256.

DAVIS AS, SchutTe BJ, IANNUZZI J \& KAREN AR (2008) Chemical and physical defense of weed seeds in relation to soil seedbank persistence. Weed Science 56, 676-684.

457 DE NeVE S \& HofMAN G (1996) Modelling N mineralization of vegetable crop residues during laboratory incubations. Soil Biology and Biochemistry 28, 1451-1457.

459 EGHBALL B \& LESOING GW (2000) Viability of weed seeds following manure windrow 460 composting. Compost Science and Utilization 8, 46-53. 
EGLEY GH \& DUKE SO (1985) Physiology of weed seed dormancy and germination. In: Weed Physiology: Reproduction and Ecophysiology, Vol. 1, (ed. SO Duke), 27-64. CRC Press FL, Boca Raton, USA.

FENNIMORE SA \& JACKSON LE (2003) Organic amendment and tillage effects on vegetable field weed emergence and seedbanks. Weed Technology 17, 42-50.

Fraser DG, DORAN JW, SAHS WW \& LeSOING GW (1988) Soil microbial populations and activities under conventional and organic management. Journal of Environmental Quality 17, 585-590.

GALLAGHER R \& FUERST P (2005) Ecophysiological basis of weed seed longevity in the soil. Weed Science Society of America Abstracts 45, 323.

Gallandt ER, FueRst EP \& KENNEDy AC (2004) Effects of tillage, fungicide seed treatment, and soil fumigation on annual mortality of Avena fatua. Weed Science 52, 597-604.

GALLANDT ER, LIEBMAN M \& HUGGINS DR (1999) Improving soil quality: implications for weed management. Journal of Crop Production, 2, 95-121.

GoGUE GJ \& EMINO ER (1979) Seed coat scarification of Albizia julibrissin Durazz. by natural mechanisms. Journal of the American Society of Horticultural Science 104, 421-423.

HALLOIN JM (1983) Deterioration resistance mechanisms in seeds. Phytopathology 73, 335339.

HANF L (1982) Ackerunkräuter Europas mit ihren Kiemlingen und Samen. BASF, Ludwigshaven, Germany.

Jensen LS, SALo T, PaLmason F et al. (2005) Influence of biochemical quality on C and N mineralisation from a broad variety of plant materials in soil. Plant Soil 273, 307-326.

KARSSEN CM \& HILHORST HWM (1992) Effect of chemical environment on seed germination. In: Seeds: the Ecology of Regeneration in Plant Communities (ed. M Fenner), 327-348. CAB International, Wallingford, UK.

KENNEDY AC \& KREMER RJ (1996) Microorganisms in weed control strategies. Journal of Production Agriculture 9, 480-485. 
KOZDROJ J \& VAN ELSAS JD (2001) Structural diversity of micro-organisms in chemically perturbed soil assessed by molecular and cytochemical approaches. Journal of Microbiological Methods 43, 197-212.

KREMER RJ \& LI J (2003) Developing weed-suppressive soils through improved soil quality management. Soil and Tillage Research 72, 193-202.

LeRoY B (2008) Soil Food Web, C and N Transformations and Soil Structure: Interactions and Feedback Mechanisms as Function of the Quality of Exogenous Organic Matter. PhD thesis, Ghent University, Ghent.

MARSchneR P, KandeleR E \& MARSchneR B (2003) Structure and function of the soil microbial community in a long-term fertilizer experiment. Soil Biology and Biochemistry 35, 453-461.

PITTY A, StANIFORTH DW \& TIFFANy LH (1987) Fungi association with caryopses of Setaria species from field-harvested seeds and from two tillage systems. Weed Science 35 , 319-323.

PLEASANT JM \& SCHLATHER J (1994) Incidence of weed seed in cow (Bos sp.) manure and its importance as a weed source for cropland. Weed Technology 8, 304-310.

Riemens MM, Groeneveld RMW, Lotz LAP \& KropfF MJ (2007). Effects of three management strategies on the seedbank, emergence and the need for hand weeding in an organic arable cropping system. Weed Research 47, 442-451

SWEENEY AE, RENNER, KA, LABOBSKI C \& DAVIS A (2008) Effect of fertilizer nitrogen on weed emergence and growth. Weed Science 56, 714-721.

TER BRAak CJF \& SMILAUER P (1998) CANOCO Reference Manual and User's Guide to Canoco for Windows: Software for Canonical Community Ordination (version 4). Microcomputer Power, Ithaca, NY, USA.

Van Der MelJden R (2005) Heukels' Flora of the Netherlands. Wolters-Noordhoff, Groningen, the Netherlands. 


\section{Figure legends}

518 Fig. 1 PCA ordination plot of weed seed bank species (depicted with BAYER codes) and 519 environmental variables. CAPBP, Capsella bursa-pastoris; CARHI, Cardamine hirsuta; 520 CERGL, Cerastium glomeratum; CHEAL, Chenopodium album; CHEPO, Chenopodium 521 polyspermum; EPIAC, Epilobium ciliatum; GASCI, Galinsoga quadriradiata; GNAUL, 522 Gnaphalium uliginosum; IUNBU, Juncus bufonius; LAMPU, Lamium purpureum; MATCH, 523 Matricaria chamomilla; PLAMA, Plantago major subsp. major; POAAN, Poa annua; POLAV, 524 Polygonum aviculare; POLPE, Polygonum maculosa; SAIPR, Sagina procumbens; SENVU, 525 Senecio vulgaris; SOLNI, Solanum nigrum; SONOL, Sonchus oleraceus; STEME, Stellaria 526 media; TAROF, Taraxacum officinale. Solid dots represent centroids of six fertilization 527 systems: FYM, farmyard manure; VFG, vegetable fruit and garden compost; CMC1, farm 528 compost with high C:N ratio 20-40; CMC2, farm compost with low C:N ratio; CSL, cattle 529 slurry; MIN N, only mineral N.

531 Fig. 2 Linear regression between total weed seed bank density and total microbial PLFA 532 content (left) and soil organic carbon content (right). 
537 TABLES 
538 Table 1 Applied amounts of organic amendments and their $\mathrm{C}$ and $\mathrm{N}$ content, and the applied 539 amount of extra mineral $\mathrm{N}$ for the fertilizer systems (FYM, farmyard manure; VFG, vegetable 540 fruit and garden compost; CMC1, farm compost with high $\mathrm{C}: \mathrm{N}$ ratio 20-40; CMC2, farm 541 compost with low C:N ratio; CSL, cattle slurry; MIN N, only mineral N)

\begin{tabular}{|c|c|c|c|c|}
\hline \multirow{3}{*}{$\begin{array}{l}\text { Fertilization } \\
\text { system }\end{array}$} & \multicolumn{3}{|l|}{ Organic fertilizer } & \multirow{3}{*}{$\begin{array}{l}\text { Applied } \\
\text { extra mineral } \mathrm{N}\end{array}$} \\
\hline & C content & $\mathrm{N}$ content & $\begin{array}{l}\text { Applied } \\
\text { amount }\end{array}$ & \\
\hline & ( $\mathrm{g} \mathrm{kg}^{-1}$ fresh matter) & $\left(\mathrm{g} \mathrm{kg}^{-1}\right.$ fresh matter) & $\left(\mathrm{kg} \mathrm{ha}^{-1}\right)$ & \\
\hline \multicolumn{5}{|c|}{ Application $1\left(21.04 .2005,4000 \mathrm{~kg} \mathrm{C} \mathrm{ha}^{-1}\right)$ : prior to sowing of fodder beet } \\
\hline FYM & 62.2 & 4.7 & 64329 & 105 \\
\hline VFG & 179.4 & 15.2 & 22303 & 114 \\
\hline CMC1 & 71.4 & 1.7 & 56007 & 165 \\
\hline CMC2 & 59.7 & 2.8 & 67058 & 165 \\
\hline CSL + straw & $26.7^{3} / 378.0$ & $3.9^{3} / 5.5$ & $77382^{2}+4704$ & \\
\hline MIN N & - & - & - & 165 \\
\hline
\end{tabular}

Application $2\left(06.10 .2005,4000 \mathrm{~kg} \mathrm{C} \mathrm{ha}^{-1}\right)$ : prior to sowing of winter wheat

$\begin{array}{lllll}\text { FYM } & 106.8 & 6.8 & 67453 & 81+97^{1} \\ \text { VFG } & 175.7 & 14.5 & 22770 & 88+98^{1} \\ \text { CMC1 } & 71.8 & 3.1 & 55718 & 91+99^{1} \\ \text { CMC2 } & 77.9 & 7.2 & 51348 & 89+97^{1} \\ \text { CSL + beet leaves } & 20.4^{3} / 49.1 & 2.8^{3} / 3.4 & 74698^{2}+53636 & 74+94^{1} \\ \text { MIN N } & - & - & - & 91+98^{1}\end{array}$

Application $3\left(07.09 .2006,1500 \mathrm{~kg} \mathrm{C} \mathrm{ha}^{-1}\right)$ : prior to sowing of phacelia

$\begin{array}{lcccc}\text { FYM } & 104.2 & 6.7 & 14398 & 66 \\ \text { VFG } & 183.2 & 15.5 & 8188 & 67 \\ \text { CMC1 } & 77.6 & 4.1 & 19330 & 86 \\ \text { CMC2 } & 63.1 & 3.4 & 23757 & 86 \\ \text { CSL } & 26.4^{3} & 3.8^{3} & 56754^{2} & \\ \text { MIN N } & - & - & - & 86\end{array}$

86

Application 4 (02.05.07, $\left.2000 \mathrm{~kg} \mathrm{C} \mathrm{ha}^{-1}\right)$ : prior to planting of red cabbage

$\begin{array}{lclll}\text { FYM } & 104.6 & 6.1 & 19125 & 106 \\ \text { VFG } & 139.6 & 9.1 & 14329 & 103 \\ \text { CMC1 } & 192.0 & 3.6 & 10417 & 170 \\ \text { CMC2 } & 91.0 & 6.0 & 21986 & 162 \\ \text { CSL } & 28.1^{3} & 3.2^{3} & 71287^{2} & \\ \text { MIN N } & - & - & - & 162\end{array}$

Application $5\left(21.05 .2008,1101 \mathrm{~kg} \mathrm{C} \mathrm{ha}^{-1}\right)$ : prior to sowing of perennial ryegrass

$\begin{array}{lrrrr}\text { FYM } & 76.0 & 5.9 & 14488 & 66 \\ \text { VFG } & 130.6 & 9.0 & 8436 & 50 \\ \text { CMC1 } & 125.2 & 4.7 & 8800 & 97 \\ \text { CMC2 } & 130.3 & 9.3 & 8452 & 125 \\ \text { CSL } & 34.2 & 4.5 & 32222 & 109 \\ \text { MIN N } & - & - & - & \end{array}$

Application 6 (11.05.2009, $\left.3259 \mathrm{~kg} \mathrm{C} \mathrm{ha}^{-1}\right)$ : prior to sowing of fodder maize

\begin{tabular}{lcccc} 
FYM & 74.3 & 2.8 & 43889 & 190 \\
VFG & 130.6 & 9.0 & 24960 & 164 \\
CMC1 & 124.4 & 4.7 & 26198 & 235 \\
CMC2 & 84.7 & 9.3 & 38474 & 248 \\
CSL & 34.7 & 3.9 & 93872 & \\
MIN N & - & - & - & 232 \\
\hline
\end{tabular}

${ }^{1}$ Fractionated $\mathrm{N}$ dose applied on 23.03.2006 and 26.04.2006

${ }^{2} \mathrm{Lha}^{-1}$

${ }^{3} \mathrm{~g} \mathrm{~L}^{-1}$ 
543 Table 2 Sowing date, harvest date and pesticide applications in subsequent crops from 2005

544 to 2009

\begin{tabular}{|c|c|c|c|c|c|c|}
\hline \multirow[t]{2}{*}{ Year } & \multirow[t]{2}{*}{ Crop } & \multirow{2}{*}{$\begin{array}{l}\text { Sowing } \\
\text { date }\end{array}$} & \multirow{2}{*}{$\begin{array}{l}\text { Harvest } \\
\text { date }\end{array}$} & \multicolumn{3}{|l|}{ Pesticide application $†$} \\
\hline & & & & Dose & Type & Date \\
\hline \multirow[t]{2}{*}{2005} & fodder beet & 22.04 & 04.10 & $3 \mathrm{~kg} \mathrm{ha}^{-1}$ Goltix $+0.6 \mathrm{~L} \mathrm{ha}^{-1}$ Vegelux & herbicide & 24.05 \\
\hline & & & & $3 \mathrm{~kg} \mathrm{ha}^{-1}$ Goltix $+0.6 \mathrm{~L} \mathrm{ha}^{-1}$ Vegelux $+1 \mathrm{~L} \mathrm{ha}^{-1}$ Eloge & herbicide & 02.06 \\
\hline \multirow[t]{3}{*}{2006} & winter wheat & 07.10 .2005 & 07.08 & $3 \mathrm{~L} \mathrm{ha}^{-1}$ Azur & herbicide & 07.04 \\
\hline & & & & $1 \mathrm{~L} \mathrm{ha}^{-1}$ Horizon & fungicide & 03.05 \\
\hline & phacelia & 07.09 & & $1 \mathrm{~L} \mathrm{ha}^{-1}$ Eloge & herbicide & 16.10 \\
\hline \multirow[t]{5}{*}{2007} & red cabbage & 22.05 & 02.10 & Dursban, $100 \mathrm{ml}$ per plant $(0.15 \%$ solution $)$ & insecticide & 22.05 \\
\hline & & & & $4 \mathrm{~L} \mathrm{ha}^{-1}$ Ramrod & herbicide & 30.05 \\
\hline & & & & $1.65 \mathrm{~kg} \mathrm{ha}^{-1}$ Lentagran & herbicide & 10.06 \\
\hline & & & & $1.5 \mathrm{~L} \mathrm{ha}^{-1}$ Okapi & insecticide & $18.06,27.06$ \\
\hline & & & & & & and 12.07 \\
\hline \multirow[t]{2}{*}{2008} & perennial ryegrass & 21.05 & $02.07,01.08$ & & & \\
\hline & & & and 12.11 & & & \\
\hline 2009 & silage maize & 11.05 & 17.09 & $\begin{array}{l}0.9 \mathrm{~L} \mathrm{ha}^{-1} \text { Frontier }+0.9 \mathrm{~L} \mathrm{ha}^{-1} \text { Mikado }+ \\
0.9 \mathrm{~L} \mathrm{ha}^{-1} \text { Samson } 4 \mathrm{SC}\end{array}$ & herbicide & 05.06 \\
\hline
\end{tabular}

† Frontier (900 $\mathrm{g} \mathrm{L}^{-1}$ dimethenamid, EC, BASF); Goltix (70\% metamitron, WG, MAKTESHIM-AGAN); Mikado (300 g L ${ }^{-1}$ sulcotrione, SC, BAYER); Samson $4 \mathrm{SC}$ (40 $\mathrm{g} \mathrm{L}^{-1}$ nicosulfuron, SC, BELCHIM); Vegelux (832 $\mathrm{g} \mathrm{L}^{-1}$ liquid paraffin, EC, SAFIC-ALCAN); Eloge (108 g L ${ }^{-1}$ haloxyfop-R-methyl, EC, DOW AGRO); Azur (20 g L-1 diflufenican + $100 \mathrm{~g} \mathrm{~L}^{-1}$ ioxynil $+400 \mathrm{~g} \mathrm{~L}^{-1}$ isoproturon, SC, BAYER); Horizon

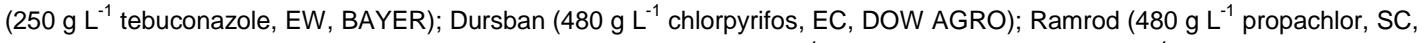
MONSANTO); Lentagran (45\% pyridate, WP, BELCHIM); Okapi ( $5 \mathrm{~g} \mathrm{~L}^{-1}$ lambda-cyhalothrin $+100 \mathrm{~g} \mathrm{~L}^{-1}$ pirimicarb, EC, SYNGENTA). 
548 Table 3 Mean seed bank density (seedlings $\mathrm{m}^{-2}$ ) for the main weed species emerged from 549 the seed bank for all fertilization systems (FYM, farmyard manure; VFG, vegetable fruit and 550 garden compost; CMC1, farm compost with high C:N ratio 20-40; CMC2, farm compost with 551 low C:N ratio; CSL, cattle slurry; MIN N, only mineral N). Values are means \pm standard errors 552

\begin{tabular}{|c|c|c|c|c|c|c|}
\hline & FYM & VFG & $\mathrm{CMC1}$ & $\mathrm{CMC2}$ & CSL & MIN N \\
\hline \multicolumn{7}{|l|}{ Species } \\
\hline Capsella bursa-pastoris & $895 \pm 128.4^{\mathrm{ab}}$ & $721 \pm 264.7^{\mathrm{ab}}$ & $1078 \pm 191.7^{\mathrm{ab}}$ & $555 \pm 200.0^{b}$ & $1434 \pm 528.2^{a}$ & $904 \pm 181.3^{\mathrm{ab}}$ \\
\hline Cardamine hirsuta & $17 \pm 16.6^{a}$ & $41 \pm 41.4^{\mathrm{a}}$ & $8 \pm 8.3^{a}$ & $41 \pm 15.9^{a}$ & $25 \pm 24.9^{a}$ & $17 \pm 16.6^{a}$ \\
\hline Cerastium glomeratum & $99 \pm 52.4^{\mathrm{ab}}$ & $99 \pm 44.9^{\mathrm{ab}}$ & $41 \pm 31.4^{b}$ & $75 \pm 8.3^{a b}$ & $108 \pm 34.2^{\mathrm{a}}$ & $41 \pm 15.9^{\mathrm{ab}}$ \\
\hline Chenopodium album $\dagger$ & $124 \pm 24.9^{\mathrm{ab}}$ & $116 \pm 55.0^{a b}$ & $257 \pm 68.2^{a}$ & $108 \pm 59.6^{b}$ & $356 \pm 247.5^{\mathrm{a}}$ & $323 \pm 122.9^{\mathrm{a}}$ \\
\hline Chenopodium polyspermum $†$ & $754 \pm 526.9^{\mathrm{ab}}$ & $688 \pm 507.6^{\mathrm{ab}}$ & $274 \pm 108.6^{b}$ & $356 \pm 174.1^{\mathrm{ab}}$ & $522 \pm 208.6^{\mathrm{ab}}$ & $1020 \pm 386.3^{a}$ \\
\hline Gnaphalium uliginosum & $191 \pm 84.9^{a}$ & $116 \pm 58.2^{\mathrm{a}}$ & $58 \pm 36.8^{a}$ & $66 \pm 35.8^{a}$ & $116 \pm 28.7^{\mathrm{a}}$ & $99 \pm 77.8^{a}$ \\
\hline Lamium purpureum & $75 \pm 53.1^{\mathrm{ab}}$ & $8 \pm 8.3^{b}$ & $91 \pm 36.8^{a}$ & $41 \pm 15.9^{a b}$ & $116 \pm 82.9^{a}$ & $50 \pm 9.6^{\mathrm{ab}}$ \\
\hline Plantago major subsp. major $\dagger$ & $986 \pm 456.3^{\mathrm{ab}}$ & $713 \pm 365.6^{a b}$ & $356 \pm 147.9^{b}$ & $414 \pm 193.6^{b}$ & $1550 \pm 565.7^{a}$ & $903 \pm 583.2^{a b}$ \\
\hline Poa annua & $812 \pm 405.3^{a}$ & $274 \pm 56.4^{\mathrm{a}}$ & $1442 \pm 707.6^{a}$ & $348 \pm 113.7^{\mathrm{a}}$ & $2926 \pm 2382.2^{a}$ & $738 \pm 549.1^{\mathrm{a}}$ \\
\hline Polygonum aviculare $\dagger$ & $199 \pm 77.8^{a}$ & $91 \pm 36.8^{\mathrm{ab}}$ & $191 \pm 31.4^{\mathrm{a}}$ & $133 \pm 70.3^{\mathrm{ab}}$ & $66.3 \pm 30.3^{b}$ & $66 \pm 23.4^{b}$ \\
\hline Polygonum maculosa $\dagger$ & $33 \pm 23.4^{\mathrm{a}}$ & $91 \pm 53.1^{\mathrm{a}}$ & $66 \pm 23.4^{a}$ & $66 \pm 35.8^{a}$ & $108 \pm 65.4^{\mathrm{a}}$ & $124 \pm 15.9^{a}$ \\
\hline Senecio vulgaris & $75 \pm 43.6^{a}$ & $50 \pm 28.7^{a}$ & $75 \pm 15.9^{a}$ & $58 \pm 8.3^{a}$ & $157 \pm 66.8^{a}$ & $25 \pm 15.9^{a}$ \\
\hline Solanum nigrum $\dagger$ & $91 \pm 31.4^{\mathrm{a}}$ & $124 \pm 15.9^{a}$ & $108 \pm 8.3^{a}$ & $108 \pm 34.2^{a}$ & $191 \pm 90.2^{a}$ & $133 \pm 30.3^{a}$ \\
\hline Stellaria media & $182 \pm 84.0^{a b}$ & $158 \pm 68.2^{b}$ & $182 \pm 28.7^{\mathrm{ab}}$ & $232 \pm 64.9^{\mathrm{ab}}$ & $580 \pm 198.3^{a}$ & $141 \pm 62.6^{b}$ \\
\hline Total seed bank & $4783 \pm 940.2^{a b}$ & $3382 \pm 977.3^{b}$ & $4543 \pm 834.8^{\mathrm{ab}}$ & $2710 \pm 424.3^{b}$ & $8463 \pm 3216.4^{\mathrm{a}}$ & $4741 \pm 956.7^{\mathrm{ab}}$ \\
\hline
\end{tabular}

† Species with hard seed coat.

No significant differences between figures with the same letter (Fisher's LSD on fourth-root transformed data, $P=0.05$ ), comparison

553 within rows only. 
555 Table 4 DM yield $\left(\mathrm{t} \mathrm{ha}^{-1}\right.$ ) of subsequent crops for all fertilization systems (FYM, farmyard 556 manure; VFG, vegetable fruit and garden compost; $\mathrm{CMC} 1$, farm compost with high C:N ratio 557 20-40; CMC2, farm compost with low C:N ratio; CSL, cattle slurry; MIN N, only mineral N).

558 Values are means \pm standard errors

\begin{tabular}{|c|c|c|c|c|c|c|c|c|}
\hline \multirow[t]{2}{*}{ Year } & \multirow[t]{2}{*}{ Crop } & \multirow[t]{2}{*}{ Crop part } & \multicolumn{6}{|c|}{ Fertilization system } \\
\hline & & & FYM & VFG & $\mathrm{CMC1}$ & CMC2 & CSL & MIN N \\
\hline \multirow[t]{2}{*}{2005} & beet & roots & $16.5 \pm 0.71$ & $16.0 \pm 0.34$ & $16.8 \pm 0.81$ & $17.7 \pm 0.26$ & $13.3 \pm 1.14$ & $18.4 \pm 0.80$ \\
\hline & & leaves & $6.9 \pm 0.17$ & $6.8 \pm 0.42$ & $7.3 \pm 0.38$ & $7.5 \pm 0.54$ & $5.4 \pm 0.28$ & $7.1 \pm 0.26$ \\
\hline \multirow[t]{2}{*}{2007} & cabbage & heads & $7.5 \pm 0.24$ & $7.5 \pm 0.06$ & $7.1 \pm 0.37$ & $7.4 \pm 0.30$ & $7.5 \pm 0.45$ & $7.1 \pm 0.15$ \\
\hline & & leaves & $6.7 \pm 0.17$ & $6.8 \pm 0.19$ & $6.2 \pm 0.32$ & $6.7 \pm 0.07$ & $7.0 \pm 0.39$ & $6.7 \pm 0.53$ \\
\hline 2008 & ryegrass & aboveground biomass & $6.1 \pm 0.22$ & $5.2 \pm 0.28$ & $5.6 \pm 0.23$ & $6.7 \pm 0.10$ & $5.1 \pm 0.33$ & $4.6 \pm 0.49$ \\
\hline 2009 & maize & aboveground biomass & $22.3 \pm 0.39$ & $20.0 \pm 0.54$ & $21.0 \pm 0.65$ & $21.7 \pm 0.38$ & $17.8 \pm 0.64$ & $20.3 \pm 0.44$ \\
\hline
\end{tabular}


562 Table 5 Total amount of PLFAs, amount of PLFAs of fungi and bacteria, bacteria to fungi 563 ratio and soil organic carbon content for all fertilization systems (FYM, farmyard manure; 564 VFG, vegetable fruit and garden compost; CMC1, farm compost with high C:N ratio 20-40; 565 CMC2, farm compost with low C:N ratio; CSL, cattle slurry; MIN N, only mineral N). Values 566 are means \pm standard errors

\begin{tabular}{|c|c|c|c|c|c|c|}
\hline & FYM & VFG & CMC1 & CMC2 & CSL & MIN N \\
\hline \multicolumn{7}{|c|}{$\begin{array}{l}\text { Amount of PLFAs : } \\
\text { (ng g }{ }^{-1} \text { soil) }\end{array}$} \\
\hline Total & $7638 \pm 422.5^{a}$ & $7362 \pm 363.5^{\mathrm{ab}}$ & $7456 \pm 313.0^{\mathrm{ab}}$ & $7415 \pm 160.5^{\mathrm{ab}}$ & $6936 \pm 297.0^{b}$ & $5591 \pm 162.5^{b}$ \\
\hline Fungi & $276 \pm 14.9^{b}$ & $323 \pm 23.7^{\mathrm{ab}}$ & $382 \pm 35.9^{a}$ & $306 \pm 9.9^{\mathrm{ab}}$ & $274 \pm 19.1^{b}$ & $275 \pm 41.7^{b}$ \\
\hline Actinomycetes & $396 \pm 15.7^{\mathrm{a}}$ & $377 \pm 20.1^{a}$ & $395 \pm 14.7^{\mathrm{a}}$ & $389 \pm 6.8^{a}$ & $366 \pm 20.4^{a}$ & $306 \pm 6.1^{b}$ \\
\hline Gram-positive & $1255 \pm 106.6^{a}$ & $1222 \pm 102^{a}$ & $1217 \pm 46.8^{a}$ & $1245 \pm 66.4^{a}$ & $1188 \pm 17.1^{a}$ & $841 \pm 60.6^{b}$ \\
\hline Gram-negative & $154 \pm 9.0^{a}$ & $143 \pm 11.1^{\mathrm{ab}}$ & $141 \pm 4.2^{\mathrm{ab}}$ & $137 \pm 0.5^{b}$ & $143 \pm 2^{a b}$ & $116 \pm 5.9^{c}$ \\
\hline Bacteria/fungi ratio & $6.7 \pm 0.11^{a}$ & $5.6 \pm 0.42^{\mathrm{ab}}$ & $4.8 \pm 0.32^{b}$ & $5.9 \pm 0.14^{\mathrm{ab}}$ & $6.5 \pm 0.44^{a}$ & $5.1 \pm 0.87^{b}$ \\
\hline Soil organic C (\%) & $1.26 \pm 0.056^{\mathrm{a}}$ & $1.27 \pm 0.074^{\mathrm{a}}$ & $1.21 \pm 0.052^{a}$ & $1.26 \pm 0.034^{\mathrm{a}}$ & $1.18 \pm 0.071^{a b}$ & $1.12 \pm 0.044^{b}$ \\
\hline $\mathrm{pH}-\mathrm{KCl}$ & $6.0 \pm 0.06^{\mathrm{ab}}$ & $6.1 \pm 0.06^{a}$ & $5.8 \pm 0.03^{c}$ & $5.9 \pm 0.08^{b}$ & $6.0 \pm 0.04^{\mathrm{ab}}$ & $5.6 \pm 0.11^{d}$ \\
\hline
\end{tabular}

No significant differences between figures with the same letter (Fischer's LSD , P $=0.05$ ), comparison within rows only. 
568 Table 6 Pearson's correlation coefficients between fourth-root transformed weed seed bank

569 densities of main seed bank species and bacterial, fungal and total microbial PLFA content

570 and soil organic carbon content

571

\begin{tabular}{|c|c|c|c|c|c|c|c|}
\hline & Total & Fungi & $\begin{array}{l}\text { Gram- } \\
\text { positive }\end{array}$ & $\begin{array}{l}\text { Gram- } \\
\text { negative }\end{array}$ & $\begin{array}{l}\text { Actino- } \\
\text { mycetes }\end{array}$ & $\begin{array}{l}\text { Soil organic } \\
\text { C content }\end{array}$ & $\mathrm{H}-\mathrm{KCl}$ \\
\hline \multicolumn{8}{|l|}{ Species: } \\
\hline Capsella bursa-pastoris & -0.19 & 0.03 & -0.16 & 0.03 & -0.21 & -0.39 * & -0.19 \\
\hline Cardamine hirsuta & 0.19 & -0.10 & 0.23 & 0.14 & 0.12 & -0.06 & 0.04 \\
\hline Cerastium glomeratum & 0.07 & -0.35 * & 0.26 & 0.18 & -0.03 & 0.09 & 0.34 * \\
\hline Chenopodium album & -0.25 & -0.01 & -0.10 & -0.04 & -0.28 & -0.23 & -0.11 \\
\hline Chenopodium polyspermum & $-0.57^{* *}$ & -0.23 & $-0.63^{* * *}$ & $-0.57^{* *}$ & $-0.52 * *$ & -0.03 & -0.37 * \\
\hline Gnaphalium uliginosum & 0.03 & -0.02 & 0.04 & -0.05 & -0.01 & 0.03 & 0.31 \\
\hline Lamium purpureum & -0.17 & -0.05 & -0.01 & -0.03 & -0.12 & -0.12 & -0.23 \\
\hline Plantago major subsp. major & -0.25 & -0.21 & $-0.30 *$ & -0.17 & -0.26 & -0.29 * & 0.00 \\
\hline Poa annua & -0.04 & -0.28 & 0.13 & 0.16 & -0.11 & -0.15 & 0.06 \\
\hline Polygonum aviculare & 0.36 * & 0.00 & 0.43 * & 0.40 * & 0.34 * & 0.12 & 0.25 \\
\hline Polygonum maculosa & -0.01 & 0.16 & 0.09 & 0.06 & -0.18 & $-0.59 * *$ & -0.25 \\
\hline Senecio vulgaris & 0.19 & -0.09 & 0.33 * & 0.27 & 0.18 & 0.21 & 0.14 \\
\hline Solanum nigrum & -0.09 & -0.03 & -0.06 & -0.14 & -0.20 & -0.40 * & -0.23 \\
\hline Stellaria media & 0.14 & -0.12 & 0.34 * & 0.28 & 0.18 & 0.17 & 0.43 * \\
\hline Total seed bank & -0.34 * & -0.20 & -0.23 & -0.12 & $-0.41 *$ & -0.44 * & -0.10 \\
\hline
\end{tabular}

572

${ }^{*} P<0.05 ;{ }^{* *} P<0.01 ; P<0.001$ otherwise $P>0.05$.

573 
574 FIGURES 


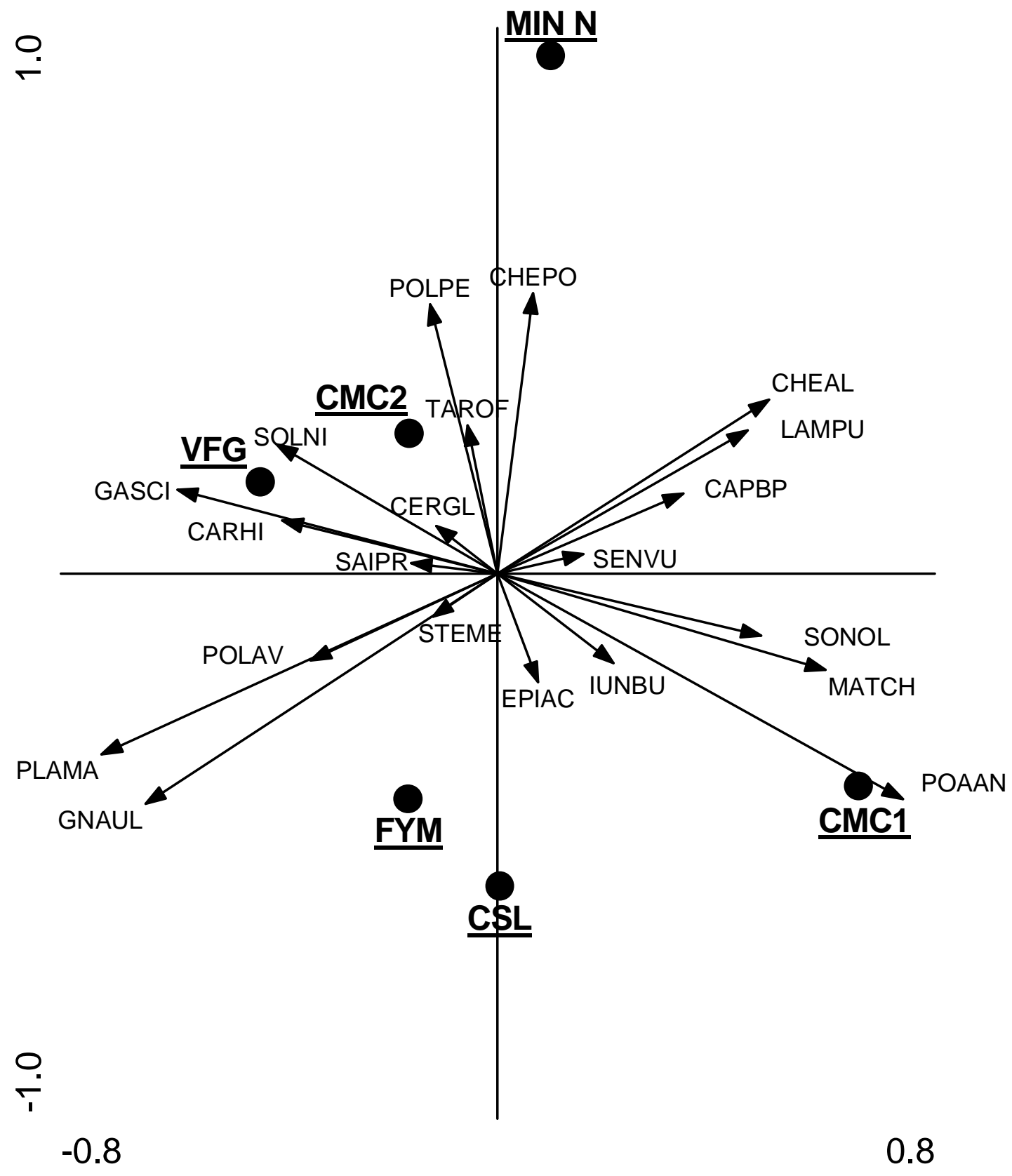

576 Fig. 1 PCA ordination plot of weed seed bank species (depicted with BAYER codes) and 577 environmental variables. CAPBP, Capsella bursa-pastoris; CARHI, Cardamine hirsuta; 578 CERGL, Cerastium glomeratum; CHEAL, Chenopodium album; CHEPO, Chenopodium 579 polyspermum; EPIAC, Epilobium ciliatum; GASCI, Galinsoga quadriradiata; GNAUL, 580 Gnaphalium uliginosum; IUNBU, Juncus bufonius; LAMPU, Lamium purpureum; MATCH, 581 Matricaria chamomilla; PLAMA, Plantago major subsp. major; POAAN, Poa annua; POLAV, 
582 Polygonum aviculare; POLPE, Polygonum maculosa; SAIPR, Sagina procumbens; SENVU, 583 Senecio vulgaris; SOLNI, Solanum nigrum; SONOL, Sonchus oleraceus; STEME, Stellaria 584 media; TAROF, Taraxacum officinale. Solid dots represent centroids of six fertilization 585 systems: FYM, farmyard manure; VFG, vegetable fruit and garden compost; $\mathrm{CMC1}$, farm 586 compost with high C:N ratio 20-40; CMC2, farm compost with low C:N ratio; CSL, cattle 587 slurry; MIN N, only mineral N. 

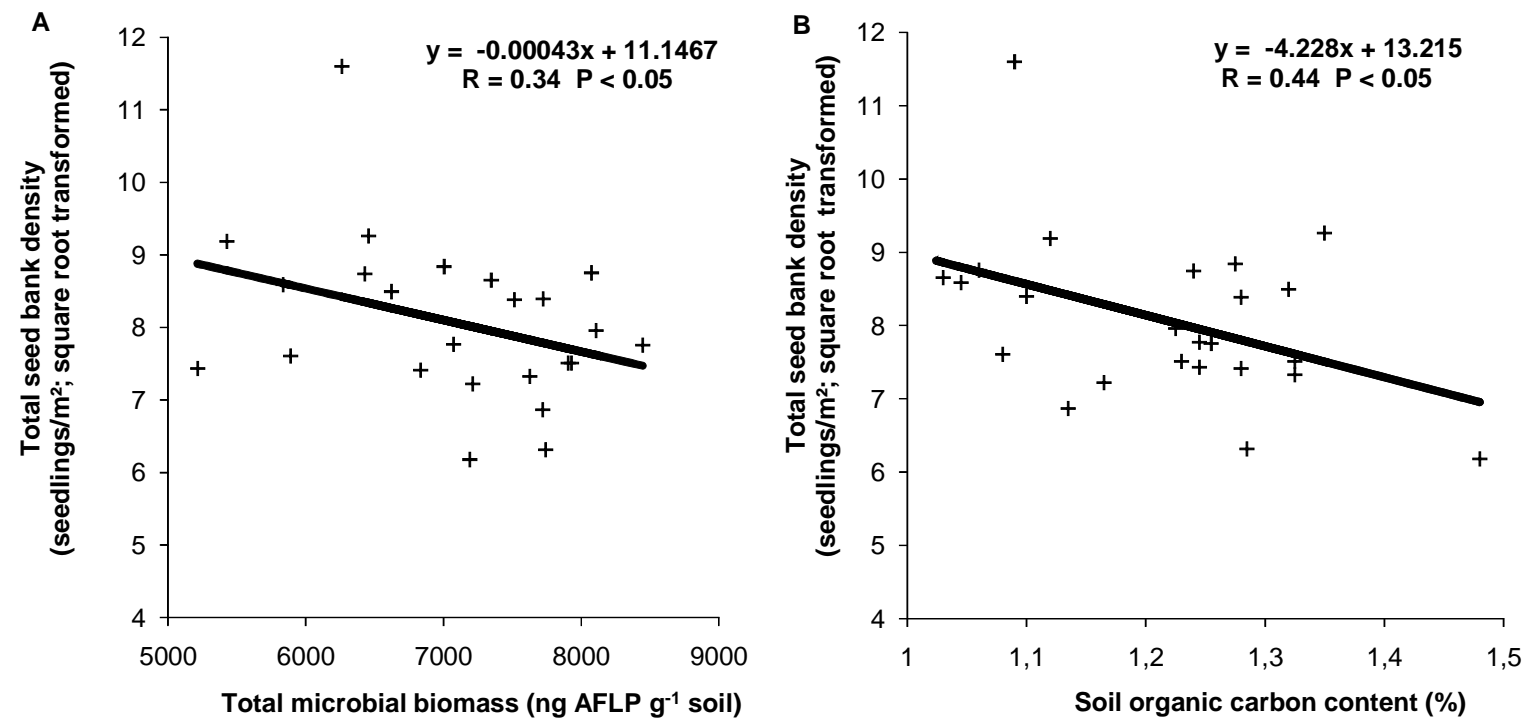

588

589 Fig. 2 Linear regression between total weed seed bank density and total microbial PLFA

590 content (left) and soil organic carbon content (right).

591

592

593

594

595 